\title{
GEOLOGIA, LITOGEOQUíMICA E POTENCIAL METALOGENÉTICO DE ROCHAS BÁSICAS E ULTRABÁSICAS NO GRUPO BRUSQUE-SC \\ ALEXANDRE BARTOSIEVICZ*
}

\author{
DISSERTAÇÃO DE MESTRADO - Programa de Pós-Graduação em Geologia - UFPR \\ DATA DE DEFESA: 2 set. 1999
}

De ocorrência muito ampla, o magmatismo básico e ultrabásico desperta muito interesse, quer seja do ponto de vista tectônico, pois são excelentes "markers", ou pelas mineralizações a ele associadas (quer seja na forma de grandes complexos ou na forma de pequenos e descontínuos depósitos). O presente estudo pretende contribuir para o avanço do conhecimento geológico e metagenético do magmatismo básico e ultrabásico, inserido no contexto do Grupo Brusque. Procurou-se aplicar e inter-relacionar dados geológicos e litogeoquímicos, na caracterização deste tipo de magmatismo, o qual está situado num ambiente modificado por processos tectonometamórficos, de idade Meso/Neoproterozóica inserido no escudo do leste catarinense. Vários trabalhos foram feitos na região, desde os de cunho petrológico, estrutural, geoquímico até os voltados à descoberta de depósitos minerais, principalmente ouro, sendo que a integração destes dados serviu de apoio ao desenvolvimento do trabalho. Os estudos foram concentrados nas duas maiores ocorrências deste tipo de magmatismo. A primeira área de ocorrência, a qual já foi objeto de estudo petrológico, situada a SW da cidade de Botuverá, é denominada de Ribeirão do Ouro, sendo composta principalmente por metagabros e metabasaltos finos, com ocorrências de metaperidotitos e metabasaltos variolíticos, está inserida em meio a metassedimentos pelíticos, psamíticos e metacalcários, e entre duas grandes intrusões batolíticas (Complexo Guabiruba e Valsungana). A segunda ocorrência, situa-se a norte das cidades, levando o nome da primeira localidade, composta por actinolititos, tremolititos, metabasaltos, por vezes com fragmentos de aglomerados de olivina, que estão associados a rochas vulcanogênicas exalativas (formações ferríferas bandadas, quartzo turmalinitos), calciossilicáticas, quartzitos, xistos magnesianos e grafitosos sendo recobertos por espesso pacote de xistos e metapelitos finos laminados. Ambas as seqüências foram intensamente deformadas por dobramentos complexos (ao menos três fases), com vergência tectônica para NW e afetadas por um grande sistema de transcorrência durante o Neoproterozóico. Quimicamente, as rochas apresentam diferenças significativas. Processos de contaminação por elementos alcalinos afetaram sobremaneira as rochas, promovendo grandes dispersões dos resultados quanto à saturação classificadas como toleíticas, subalcalinas, geradas em ambientes transicionais. Ao contrário, as rochas de Canelinha não mostraram evidências de contaminação significativa, sendo as mesmas classificadas como toleítos, de alto magnésio, associados a ambientes extensionais, se não completamente formados, próximos à oceanização. As seqüências têm como característica os processos de cristalização fracionada como formadores. Possibilidades de ocorrência de depósitos minerais associados a elas podem ser ligadas a complexos formados por diferenciação, ou instalados em margem passiva de continentes (Ribeirão do Ouro), ou à mineralizações associadas à geração de ambientes ocêanicos. Indiretamente, estas intrusões podem ser encaixadas em modelos do tipo ouro em zonas de cisalhamento em rochas metabásicas, além de, na região de Canelinha, poderem indicar pelo ambiente tectônico em que se instalaram, depósitos vulcanogênicos exalativos.

*E-mail: barto@ufpr.br 